\title{
TEACHERS OF PHYSICAL EDUCATION ON IMPROVING THE QUALITY OF TEACHING WITH CONTINUOUS ADJUSTMENTS TO THE CURRICULA
}

\author{
UDC 796.015:371.214:371.124
}

\author{
Marija Jovanović ${ }^{1}$, Vesna Minić ${ }^{2}$ \\ ${ }^{1}$ Faculty of Philosophy, University of Niš, Niš, Serbia \\ ${ }^{2}$ Teacher Training Faculty in Leposavić, University of Priština, Leposavić, Serbia
}

\begin{abstract}
Basic objections which are now attributed to modern teaching, its quality and efficiency are related to the curricula. Inadequate, outdated, too extensive and unadapted curricula affect the process of planning, programming and implementation of teaching and the quality of the outcomes achieved. Their continuous changing, shaping and adapting to modern conditions of life, to the demands of immediate reality and the needs and abilities of students are the basic requirements for providing the quality of modern teaching and the imperative of modern pedagogy. Given the importance they have in ensuring the quality of the implementation of the development model of teaching and the quality and effectiveness of its outcomes, the paper will view this problem in terms of their adaptation to the needs and abilities of students. The main categories through which an adjustment of the curricula to the needs and abilities of students is considered are as follows: teaching strategies, teaching materials, and the content of materials. This paper presents and analyses the results of an empirical survey on the views of physical education (PE) teachers about the above mentioned segments to adapt curricula, as well as the recommendations resulting from their direct experience.
\end{abstract}

Key words: curricula, teaching strategies, teaching material, teaching content, PE teachers

\section{INTRODUCTION}

One of the most important pedagogical issues nowadays is to ensure the quality and effectiveness of teaching. The topicality and importance of this issue stem from the requirement that the purpose of teaching is to train young people to be actively and

Received February 8, 2018 / Accepted December 31, 2018

Corresponding author: Marija Jovanović

University of Niš, Faculty of Philosophy, Ćirila i Metodija 2, 18000 Niš, Serbia

Phone: +381 18514312 •E-mail: marija.jovanovic@ filfak.ni.ac.rs 
creatively involved in social life and modern trends of the $21^{\text {st }}$ century. As many authors emphasise (Ross, 2000; Westbury, 2000; Hudson, 2003; Apple, 2004; Kelly, 2004; Anyon, 2006; Palekčić, 2006) a significant factor in ensuring the good quality of teaching is the curricula. Curricula, as basic documents which provide the framework and determine the directions of educational activities in schools, have an important role in ensuring the quality and efficiency of teaching. With their characteristics, they establish the character of teaching activities, direct and determine the outcomes of teaching and thus directly affect the quality and efficiency of the teaching process. Therefore "to a great extent, curricula development, or change, aims to maximize the effectiveness of teaching and learning through change in planned content, activities and arrangements for educational processes" (Cheng, 1994: 27). For this reason, when setting up the concept of curricula and during their development, the principle of modernity should be respected, it should be striven for the development of the individual traits of students and students should be prepared for independent, creative, critical and creative activities.

In Serbia today, curricula significantly deviate from contemporary models since the basic objections indicate "too much learning material, historicism, encyclopedism-which supports the existence of verbosity, formalism, memorization at the expense of thinking, non-differentiation,-all of which favor conformism, uncritical adoption of learning materials, passivity, inflexibility, etc." (Čanović, 2002: 188). In order for the curricula to be appropriate for use in modern education, it is necessary to pay special attention to their continuous change and improvement. Only in this way we can expect modern teaching to keep up with the novelties and provide quality and efficient education of young people.

Curricula is an official document whose elements are: "a list of subjects for students and teachers of the school for which the plan is intended, then, the sequence based on which the subjects will be studied according to students' age, weekly or annual number of teaching hours for each subject and grade, and, finally, the total number of classes for each subject" (Bakovljev, 2005: 24). Curricula is a basic prerequisite for the quality of modern teaching.

Planning and developing modern curricula, as well as changing and improving the existing ones, should be based on the following requirements: 1) curricula must be such to allow the realization of basic educational goals and tasks predicted for a certain level (degree) of education; 2) curricula must be aligned with the overall organization of the school system; 3) type of school should be taken into account as well as any special educational tasks that have been set for that type of school; 4) the age of the students should be taken into account as well as their psychological, physical and developmental characteristics; and 5) the principle of systematicity should be followed.

By acknowledging and meeting these demands there is a possibility for the curricula to be the basis for the realization of quality education which would be based on respect for the individual characteristics of students, the provision of gradualism in the course of teaching activities and the compliance of general and specific teaching objectives and tasks.

The curricula, as an official school document, defines three basic didactic dimensions of education: the scope or breadth, depth and sequence of the teaching material taught. The curricula is often defined as "the totality of all the targeted teaching, that is, the initial state of the teaching content" (Jelavić, 2008: 161). This definition is trying to indicate its approximate or tentative framework, and that the basic category of curricula is actually teaching content or material. Curricula does concretize all components of the target teaching operation which 
is carried out and turns into practice the defined theoretical teaching material, and it also affects the scope and depth of knowledge, skills and habits that students need to adopt from a particular subject in one grade (year).

The principles to bear in mind when working on a modern curricula are: 1) the teaching content/material in compliance with science; 2) compliance of educational content with educational objectives of the school; 3) the systematic teaching content in the curricula; and 4) restraint when deciding upon the scope and depth of educational content provided by the curricula.

The overall goal of the research was to examine, analyze and compare physical education (PE) teachers' views about significant aspects and possibilities of improving the quality of teaching by adapting curricula.

\section{METHODS}

The sample included $150 \mathrm{PE}$ teachers from primary schools in the municipality of Niš and Kosovska Mitrovica (town and rural schools). The structure of the sample with respect to years of service and the location of the school is presented in Table 1.

Table 1 The structure of the chosen sample

\begin{tabular}{lcccccr}
\hline Location & $\mathrm{N}$ & $\%$ & \multicolumn{4}{c}{ Years of service } \\
\cline { 3 - 7 } & & & $\begin{array}{c}1-10 \\
\text { years }\end{array}$ & $\%$ & $10-20$ years & $\%$ \\
\hline Town & 118 & $78.6 \%$ & 58 & 38.6 & 60 & 40.0 \\
Village & 32 & $21.4 \%$ & 18 & 12.0 & 14 & 9.4 \\
\hline Total & 150 & $100.0 \%$ & 76 & 50.6 & 74 & 49.4 \\
\hline
\end{tabular}

The study was carried out in two phases. In the first phase, teachers were asked to name ways to adapt curricula whose goal is to improve the quality of teaching. Based on the results established in the first phase, in the second phase of the study, class and subject teachers spoke about the possible improvement methods and gave their recommendations.

\section{RESULTS}

Research into the problem of how to improve the quality of teaching through continuous adaptations of curricula includes a study of teachers' views on four main aspects of adaptation: strategies, materials, material content and teaching practice. During the research of the attitudes of PE teachers, it was noted that the aspect of teaching practice is not seen as a key one because they think that the changes in the immediate teaching practice cannot be spoken about separately, but that these changes are rather connected with the other aspects. 
Table 2 Teachers' attitudes on aspects of curricula adaptation

\begin{tabular}{lrr}
\hline Aspects of curricula and syllabus improvement & $\mathrm{N}$ & \multicolumn{1}{c}{$\%$} \\
\hline Teaching strategies & 116 & 77.3 \\
Material content & 20 & 13.3 \\
Teaching materials & 14 & 9.4 \\
\hline Total & 150 & 100.0 \\
\hline
\end{tabular}

As it can be seen from Table $2,77.3 \%$ of teachers (116 of them) emphasize the importance of teaching strategies in improving teaching. Teaching content, and teaching materials i.e., adjustments of these are given less importance in improving the quality of teaching $(13.3 \%$ and $9.4 \%$ ). The obtained results, as can be seen, suggest pedagogical optimism in terms of changes and the possibilities of improving the quality of teaching and the importance that teachers have in this process as creators and implementers of teaching strategies.

Table 3 The attitudes of teachers on how to improve teaching strategies

\begin{tabular}{lrrrccc}
\hline Improvement methods & \multirow{2}{*}{$\mathrm{N}$} & $\%$ & \multicolumn{2}{c}{ Town } & \multicolumn{2}{c}{ Village } \\
\cline { 4 - 7 } & & & $1-10$ years & $10-20$ years & $1-10$ years & $10-20$ years \\
\hline Cooperative learning & 58 & 38.7 & 30 & 28 & 0 & 0 \\
Role plays & 4 & 2.7 & 0 & 4 & 0 & 0 \\
Brainstorming & 4 & 2.7 & 4 & 0 & 0 & 0 \\
Discussion & 44 & 29.3 & 16 & 10 & 12 & 6 \\
Workshops & 28 & 18.7 & 10 & 12 & 6 & 0 \\
Didactic games & 4 & 2.7 & 4 & 0 & 0 & 0 \\
Group work & 8 & 5.3 & 4 & 0 & 4 & 0 \\
\hline Total & 150 & 100 & \multicolumn{3}{c}{$\chi^{2}=51.480 ; \mathrm{df}=18$} & \\
\hline
\end{tabular}

According to the attitudes of teachers, teaching strategies, as the most important aspect of quality improvement, can be adjusted in many different ways. The respondents emphasize as the most important ones cooperative learning, discussion in the classroom, workshops, group work, role plays, brainstorming, and didactic games. After the survey, $\chi^{2}=51.480$ (Table 3 ) was compared to the limit values for $\chi^{2}$ from 28.869 and 34.805 , with a degree of freedom of $\mathrm{df}=18$, and on both significance levels there was a statistically significant difference in the attitudes of teachers based on the location of the schools they work in. The identified result is a consequence of the insistence of respondents from urban areas on collaborative learning as a way to improve quality. PE teachers from rural schools, unlike their counterparts in the city, see discussions, workshops and group work as the only ways to improve teaching strategies. The fact that these respondents very frequently emphasized the importance of discussions and workshops can be explained by the fact that schools in rural areas often lack gymnasiums or they are not functional, which is why PE teachers are often forced to improvise. 
Table 4 The attitudes of teachers on how to improve teaching materials

\begin{tabular}{lrrrrrr}
\hline Improvement methods & $\mathrm{N}$ & $\%$ & \multicolumn{2}{c}{ Town } & \multicolumn{2}{c}{ Village } \\
\cline { 4 - 8 } & & & $\begin{array}{c}1-10 \\
\text { years }\end{array}$ & $\begin{array}{l}10-20 \\
\text { years }\end{array}$ & $\begin{array}{r}1-10 \\
\text { years }\end{array}$ & $\begin{array}{r}10-20 \\
\text { years }\end{array}$ \\
\hline Improvements of material & 18 & 12.0 & 4 & 4 & 4 & 6 \\
Highlighting the most important details & 80 & 53.4 & 28 & 34 & 14 & 4 \\
Design of materials that have sensory effects & 18 & 12.0 & 6 & 4 & 4 & 4 \\
Selection of alternative teaching materials & 34 & 22.7 & 10 & 20 & 0 & 4 \\
\hline Total & 150 & 100.0 & \multicolumn{2}{c}{$\chi^{2}=27.804 ; \mathrm{df}=9$} & \\
\hline
\end{tabular}

Adaptation of teaching materials is an instrument to improve the quality of teaching that provides opportunities for students to work on material that is in accordance with their abilities. Although the respondents from both locations most frequently emphasized the details of improving teaching materials (Table 4), research has statistically identified significant differences in attitudes depending on the location of the respondents $\left(\chi^{2}=27.804, \mathrm{df}=9\right)$.

Table 5 The attitudes of teachers on how to improve teaching content

\begin{tabular}{|c|c|c|c|c|c|c|}
\hline \multirow[t]{2}{*}{ Improvement methods } & \multirow[t]{2}{*}{$\mathrm{N}$} & \multirow[t]{2}{*}{$\%$} & \multicolumn{2}{|c|}{ Town } & \multicolumn{2}{|c|}{ Village } \\
\hline & & & $\begin{array}{c}1-10 \\
\text { years }\end{array}$ & $\begin{array}{l}10-20 \\
\text { years }\end{array}$ & $\begin{array}{c}1-10 \\
\text { years }\end{array}$ & $\begin{array}{l}10-20 \\
\text { years }\end{array}$ \\
\hline Change of the volume of teaching content & 42 & 28.0 & 20 & 8 & 4 & 10 \\
\hline $\begin{array}{l}\text { Selection of teaching materials which } \\
\text { develop health }\end{array}$ & 14 & 9.3 & 4 & 10 & 0 & 0 \\
\hline Insistence on practical use & 16 & 10.7 & 10 & 6 & 0 & 0 \\
\hline $\begin{array}{l}\text { Selection of teaching materials that make } \\
\text { students active participants }\end{array}$ & 56 & 37.3 & 26 & 22 & 4 & 4 \\
\hline Relation of teaching materials to real life & 22 & 14.7 & 0 & 12 & 10 & 0 \\
\hline Total & 150 & 100.0 & \multicolumn{4}{|c|}{$\chi^{2}=30.994 ; \mathrm{df}=12$} \\
\hline
\end{tabular}

Selection of teaching content that renders students active participants was emphasized as the way to improve teaching material (37.3\%). A significant place among teachers was also taken by Change of the volume of teaching content and Relation of teaching materials to real life ( $28 \%$ and $14.7 \%$ ) (Table 5). The obtained $\chi^{2}=30.994$ as compared to the limit values for $\chi^{2}$ from 21.026 and 26.217, with the degree of freedom number $\mathrm{df}=12$, and on both significance levels $(0.05$ and 0.01$)$ shows that there was a statistically significant difference in the attitudes of teachers based on the location of schools they work in. The identified result is a consequence of different views on the importance of the aforementioned ways to improve teaching materials, i.e., the fact that teachers from rural schools did not recognize certain ways as valid (Insistence on practical use and Selection of teaching materials which develop health).

This result also shows that teachers from rural schools are burdened with difficult working conditions and are thus not able to solve more complex issues regarding the teaching content improvement, because their primary effort is to successfully do the teaching in conditions that are often on the edge of poverty. 


\section{DISCUSSION}

The imperative of modern pedagogy and the main challenge of teaching practice is to improve the quality of the teaching process. The complexity of this issue is caused by a number of factors which directly or indirectly influence it. "The quality and contemporarity of the teaching process in this day and age (being based on the humanistic and constructivist theoretical settings in pedagogy and didactics of "participation") should be based on, among other things, the diversity of teaching forms and the increased activity of students and teachers" (Stanojević \& Zdravković, 2013:139). Teaching curricula and syllabi are one of the most important factors ensuring the quality of teaching. This concept of the curricula is directly linked to the educational standards whose goal is "that the objectives and tasks of the teaching subjects are concretized, operationalized and translated into the measurable behavior indicators of students" (Stojanović \& Zdravković, 2017: 380). Their quality and modernity influence the process of planning, programming and implementing teaching and the quality of outcomes achieved. As important factors of the quality of teaching, curricula require continuous change, amending and adapting to modern conditions of life, to the demands of the immediate reality and the abilities and needs of students.

By pointing out the main values of education and teaching, the goals of education are "the basis for identifying the results, real effects, i.e., the outcomes of teaching process, and they affect the actual solutions in educational practice and represent one of the main starting points for the development of all educational activities" (General Curricula Framework, 2003: 21).

Professional training of teachers and other implementers of the curricula includes continuous didactic and methodological training of teachers and associates, education in the field of modern technology and training in the discipline they work in and deal with. "Professional development is a complex process that implies continuous development of competencies of teachers, educators and professional associates in order to improve their performance and to improve the development of children, pupils and students, that is, their level of achievement. An integral and mandatory part of professional development is professional training which involves the acquisition of new and improvement of the existing knowledge and skills which are important for the advancement of educational and professional work and child care" (The Official Gazette of the Republic of Serbia, 2015). Based on the continuous education and training they receive, teachers will be able to follow the modern trends of scientific disciplines to which they belong, to perform didactic and methodological modeling of creative teaching material and participate in innovation, development and improvement of their disciplines.

One of the prerequisites for successful alteration of curricula is to provide adequate teaching material. Changes must be accompanied by new, adequate textbooks, teaching materials, requisites and other educational resources. Teaching material to be prepared should include material designed for students but also materials intended for teachers. What is important is to ensure greater participation of teachers who are the direct implementers in designing and developing these materials. With their vast didactic and methodological experience and with their pedagogical and psychological knowledge of the developmental characteristics of children, the knowledge of their capabilities and needs, teachers can significantly contribute to the development of appropriate teaching plans and programs. It is particularly important that the change is the result and is based on the immediate needs of teaching. 
A modern development model of education implies the design of teaching material which: provides modern scientific knowledge; encourages students to be active; insists on the critical thinking of students; encourages creativity of students; is able to satisfy the diverse individual students' needs and interest, etc.

Effective planning and management of the process of developing and implementing the curricula is an essential link in the process of changing the curricula. This link involves the efficient activity of those individuals and services that lead and organize this process. These are primarily school principals and pedagogical and psychological services. The pedagogical head of the school (the principal) and pedagogical and psychological service in a school must create the conditions for the implementation of the curricula through the teaching process, as defined by the teaching program itself. The prerequisite to achieve this is mastery of the process that is being implemented, coordination of activities of various individuals and ensuring maximum commitment and engagement of all individual participants in the teaching process. Only the effort of the whole team, joint planning and effective leadership during the implementation of curricula changes can be effective.

Monitoring and evaluation of the results that have come from alterations of the teaching process are a key step in the process of changing the curricula. Monitoring and evaluation enable "for the true values and the results achieved to confirm and affirm both with students and the teachers. Monitoring and evaluation bring with them the dynamics, and they initiate and encourage people to achieve better results. As soon as an area of work stops being evaluated, stagnation is always a result, that is, the good practice returns to its simpler and less intensive form" (Vilotijević, 1992: 182). Therefore, monitoring and evaluation of the status of the altered teaching process should be understood as a result, but also as a prerequisite for efficient continuous curricula changes. Monitoring and evaluation process of the results of the change is a complex process and necessarily includes many elements of teaching. The elements of monitoring include data related to students, teachers and classes. Data related to students are for example: the results achieved, student engagement, interest, obstacles or problems, identified outcomes, creativity, independence, critical approach, etc.

Data related to teachers are: personal and professional information, information on professional development, involvement in teaching, obstacles faced, interaction etc. Elements of teaching that are important in the process of monitoring and evaluating changes of the curricula are: the expected and actual outcomes, applied methods, teaching methods, teaching aids, types of teaching, perceived potentials and opportunities, challenges and obstacles, interaction, etc. Adapting the curricula as a condition and a determinant of quality assurance, involves the creation of conditions where the right curricula are to provide students with a variety of opportunities and choices in the classroom. Thus understood, adaptation includes four main categories: teaching strategies, teaching materials, teaching contents and immediate practice.

From the aspect of teaching strategies, adaptation involves changes of teaching practices and of the organization of learning activities so that they themselves ensure quality and efficiency. Based on modern methodology, teaching strategy changes include changes to the procedures and actions that will enable students to receive, share and respond to the educational information and teaching material in the most appropriate way. Providing students with teaching material in a way that differs from the traditional way ensures that each student, based on their abilities and interests, achieves the objectives set, masters the 
methods and techniques of teaching, becomes independent and actively participates in the teaching process. Improving the teaching process by adapting teaching strategies, can be achieved using: cooperative forms of teaching activities, discussions, workshop method, group activities, role plays, brainstorming, didactic games, etc. "While some school programs include additional PE classes or additional activities (active breaks, activities before or after classes), others are based on curricula changes. Increasing frequency and duration is not always possible, given the competitive requirements of the curricula, so it is important to stimulate physical activity within classes and breaks, and to develop strategies for more efficient use of PE classes" (Cvejić \& Ostojić, 2017: 438).

Adaptation of teaching materials involves a change in format through which the information is presented to students during lessons. Since the process of material adaptation relates to the additional or different materials that would be used by students in a variety of modalities during teaching, most material adaptations fall into one of four groups: "Improvements of the readability of written material; Improvement of critical, that is, emphasis of the most important characteristics of teaching material; The design of materials with characteristics that affect the senses, except for visual and auditory; Selection of alternative teaching materials in accordance with the individual characteristics of students" (Udvari-Solner, 1993, 158).

Improvement of the level of readability can be achieved by providing material that is similar to the teaching unit but stated in simpler terms, consisting of more interesting topics, or it might have more complex terminology depending on the individual characteristics of the students.

This ensures that all students in accordance with their potential are motivated and invest maximum effort. This aspect of the adaptation of teaching materials can be improved by adding pictures, graphs, sketches to the text or the use of different models or teaching resources which contribute to intuition in teaching.

Improvement of critical, that is, the most important features of teaching material involves adaptation of lessons, both in terms of highlighting the details, data, and information that matter most. This type of adaptation involves activities which prepare teaching material in advance by using words in bold, highlighting key words, the main idea, re-stating the conclusions at the end of the lesson, etc. The design of materials with characteristics that affect the senses, with the exception of visual and auditory, is a significant change that contributes to the provision of quality teaching. This change involves modeling the content so that its design influences, that is, triggers and moves the multiple sensory systems of students. Instead of teaching materials that trigger only visual and auditory sensory systems, materials need to initiate and engage as many senses as possible. This is particularly important when students need to develop certain skills.

Alternative teaching materials represent a significant change that should be introduced primarily because of its durability and safe characteristics, but also to improve the physical coordination and motor skills of students. In this way, students firstly reject fear and nervousness of the possible damage that teaching materials might do, and then the conditions are created for the free use of teaching materials until the complete adoption of certain knowledge. These changes of teaching materials allow students to, in accordance with their abilities and skills, actively participate in teaching activities and thus actively acquire knowledge, develop and gain skills. 
Adapting teaching content includes various adaptations of what is taught, i.e., changes of complexity and nature of the content covered during class. The aim of the changes of teaching content is oriented towards the changes in the field of knowledge and learning where the focus moves from reproductive memory to productive and critical thinking and creativity. These changes allow students to constantly advance and develop regardless of their current abilities (Janney \& Snell, 2000). One to us well-known way of making such a change is to deal with tasks at three levels of complexity.

In order to ensure the quality of teaching, direct teaching practice is one of the important areas that require the introduction of continuous change. These changes are primarily related to the approach and attitude towards the student and the way how feedback is received from students. Interventions that are carried out in the specified area should be focused on teamwork, partnership, interaction and collaboration, as well as on the expansion of situational contexts of teaching and assessment activities. By creating a climate of teamwork and partnership, cooperation and interaction, students are made active participants and they are allowed to have an active and creative approach to teaching. The expansion of situational contexts of teaching and assessment activities creates the possibility that the primary goal of teaching is not the acquisition of knowledge but rather the creation of options and ways to establish development model of education.

\section{CONCLUSION}

Based on the results of empirical research on the attitudes of PE teachers concerning the improvement of the quality of teaching by making continuous adjustments of curricula, the following conclusions can be mentioned: 1) Alteration of teaching strategies in terms of cooperative learning, introduction of discussion, workshops, group work, role plays, brainstorming, and didactic games is the most suitable way to improve the quality of teaching; 2) PE teachers do not recognize the opportunities provided by the immediate teaching practice because they believe it is in correlation with the change of strategies, materials and contents, and that it cannot be treated individually. Changes in these areas necessarily imply changes in the area of immediate teaching practice; and 3) PE teachers in rural schools to a lesser extent recognize the ways and possibilities to improve curricula and syllabus in all the studied aspects. Faced with many existential problems posed by work in the villages on the border, teachers in this environment mention only those options that are available to them, plausible and realistic in terms of where they work.

Recommendations given by PE teachers and which arose from their direct experience are: 1) Improvement of the quality of teaching to a large extent depends on the commitment professional services which work in schools (pedagogues and psychologists); 2) Flexibility and criticism with regard to the creation of curricula are a requirement to ensure quality; 3) Planning, programming and teaching itself must have the same goal - the individualization of teaching; 4) If we want to improve the quality of teaching by altering the curricula then our main criterion and principle should be the student, his personality and development; and 5) Ensuring the quality of teaching by altering curricula requires a high degree of school autonomy concerning curricula creation, and a creative approach of the teacher to curricula creation. 
Acknowledgement: The paper is the result of research within the project: "Sustainability of identity of Serbs and ethnic minorities in the border municipalities of East and Southeast Serbia" (OI 179013), carried out at the University of Niš - Faculty of Mechanical Engineering and funded by the Ministry of Education, Science and Technological Development of Republic of Serbia and the project "Kosovo and Metohija between national identity and European integration"(III 47023), funded by the Ministry of Education, Science and Technological Development of the Republic of Serbia.

\section{REFERENCES}

Anyon, J. (2006). Social Class, School Knowledge, and the Hidden Curricula, Re-theorizing Reproduction. In L. Wies, L.C. McCarthy \& G. Dimitriadis (Eds.), Ideology, Curricula and the New Sociology of Education, Revisiting the Work of Michael Apple (pp. 37-46). New York: Routledge

Apple, M. (2004). Ideology and Curricula. New York: Routledge Falmer.

Bakovljev, M.(2005). Didaktika (Didactics). Sombor: Faculty of Pedagogy in Sombor \& Publishing Center. In Serbian

Čanović, S. (2002). Problemi savremene nastave (Problems of contemporary teaching). Leposavić: Teachers' Training Faculty, University of Priština. In Serban

Cvejić, D., \& Ostojić, S. (2017). Effects of the FITT program on physical activity and health-related fitness in primary school age children. Facta Universitatis Series Physical Education and Sport, 15(3), 437-451.

Cheng, Y. (1994). Effectiveness of curricula change in school: an organizational perspective. International Journal of Educational Management, 8(3), 26-34.

General Curricula Framework. (2003). Ministry of Education and Sports of the Republic of Serbia. Belgrade: Prosvetni pregled

Hudson, B. (2003). Approaching educational research from the tradition of critical-constructive Didaktik. Pedagogy, Culture \& Society, 11 (2), 173-186.

Janney, R., \& Snell, M. E. (2000). Teachers' guides to inclusive practices: Modifying schoolwork. Baltimore: Paul H. Brookes

Jelavić, F. (2008). Didaktika (Didactics). Zagreb: Naklada Slap. In Croatian

Kelly, A.V. (2004). The curricula, theory and practice. London: Sage Publications.

Palekčić, M. (2006). Sadržaji obrazovanja i nastave: struktura i kriteriji odabira (Content of education and teaching process: Structure and selection criteria). Pedagogijska istraživanja, 3 (2), 181-200. In Croatian

Ross, A. (2000). Curricula: Construction and Critique. London: Falmer Press.

Stanojević, D., \& Zdravković, D. (2013). Škola i drustvene promene (School and social changes). Novo Mesto: Pedagoska obzorja. In Serbian

Stojanović, S., \& Zdravković, D. (2017). Educational standards - the evaluation of the importance of physical exercise for students. Facta Universitatis Series Physical Education and Sport, 15(2), 379-390.

The Official Gazette of the Republic of Serbia (2015). Pravilnik o stalnom stručnom usavršavanju nastavnika, vaspitača i stručnih saradnika (Rulebook on continuous professional development of teachers, educators and professional associates). Službeni glasnik RS, 86/2015, Article 1 and 2. In Serbian

Udvari-Solner, A. (1993). Curricular adaptations: Accommodating the instructional needs of diverse learners in the context of general education. (Rev.) Topeka, KS: Kansas State Board of Education

Vilotijević, M. (1992). Vrednovanje pedagoškog rada škole (Evaluation of pedagogical work of the school). Belgrade: Naučna knjiga. In Serbian

Westbury, I. (2000). Teaching as reflective practice: What might Didaktik teach curricula? In I. Westbury, S., Hopmann, \& K., Riquarts (Eds.), Teaching as a reflective practice: The German didaktik tradition, (pp. 1539). Mahwah, NJ: Erlbaum 


\section{NASTAVNICI FIZIČKOG VASPITANJA O UNAPREĐIVANJU KVALITETA NASTAVE KONTINUIRANIM PRILAGOĐAVANJEM NASTAVNOG PLANA I PROGRAMA}

Osnovne zamerke koja se danas pripisuju savremenoj nastavi, njenom kvalitetu i efikasnosti, vezuju se za nastavne planove $i$ programe. Neadekvatni odnosno zastareli nastavni planovi $i$ preopširni $i$ neprilagođeni nastavni programi utiču na proces planiranja, programiranja i realizovanja nastave kao $i$ na kvalitet ostvarenih ishoda. Njihovo kontinuirano menjanje, oblikovanje i prilagođavanje savremenim uslovima života, zahtevima neposredne stvarnosti kao i potrebama i mogućnostima učenika, osnovni su uslovi obezbeđivanja kvaliteta savremenog nastavnog rada i imperativ savremene pedagogije. $S$ obzirom na značaj koji imaju u obezbeđivanju kvaliteta realizacije razvojnog modela nastave ali $i$ kvaliteta $i$ efikasnosti ostvarenih ishoda, u radu će ovaj problem biti sagledan $s$ aspekta njihovog prilagođavanja potrebama i mogućnostima učenika. Osnovne kategorije kroz koje je prilagođavanje nastavnog plana i programa potrebama i mogućnostima učenika sagledano su: nastavne strategije, nastavni materijali $i$ sadržaj nastave. $U$ radu su predstavljeni $i$ analizirani rezultati empirijskog istraživanja stavova nastavnika fizičkog vaspitanja o navedenim segmentima prilagođavanja nastavnih planova i programa kao i preporuke koje su proistekle iz njihovog neposrednog iskustva.

Ključne reči: nastavni plan i program, nastavne strategije, nastavni materijali, sadržaj nastave, nastavnici fizičkog vaspitanja. 